\title{
低電源電圧低消費電力第二世代カレントコンベア
}

\author{
非会員 今 関 勲 (東京工業大学) \\ 正員 高 木 茂 孝 (東京工業大学) \\ 正 員 藤 井 信 生 (東京工業大学)
}

\section{Low-Voltage Low-Power Second-Generation Current Conveyors}

Isao Imazeki, Non-member, Shigetaka Takagi, Member, Nobuo Fujii, Member (Tokyo Institute of Technology)

This paper proposes second-generation current conveyors (CCII's) for low supply voltage operation. The power consumption of the proposed circuits is much lower than that of a conventional circuit. A method for reducing the effect caused by channel-length modulation is also proposed. Simulation confirms several advantages of the proposed circuits.

キーワード：CCII, 低電源電圧, 低消費電力, チャネル長変調効果

1. まえがき

第二世代カレントコンベア (Second-Generation Current Conveyor; CCII) ${ }^{(1)}$ はフローティングインダクタや単位利 得周波数可変の MOS 積分器, 電圧設定回路の実現 ${ }^{(2)}$ (4) $^{(4)}$ などにおいて極めて有用なアナログビルディングブロック の一つである。近年，携帯電子機器の普及や集積回路素子 の耐圧低下に伴い，低電源電圧駆動のアナログ集積回路の 奏現が望まれており，CCIIにおいても例外ではない。従来 のCCII として，差動增幅回路とカレントミラー回路から なる簡単な構造の回路が提案されている。しかし，この回 路は，差動增幅回路部分において MOSFET が 3 段縦積み となるという問題点とカレントミラー回路が無信号時にお いても電力を消費し，また出力電流を制限するという問題 点を有している。

本論文では，従来の CCII を改良することにより，低電 源電圧駆動，低消費電力の CCII を提案する。提案回路は, 電源間にMOSFETを 2 個だけ縦積みとしており，低電源 電圧での使用に適している。また, 電流出力段として用い られていたカレントミラー回路の代わりに相補動作するカ レントミラー回路を用いることにより，入力に応じて一部 の電流出力回路だけを動作させることで消費電力の大幅な 低減を実現する。さらに，回路特性を劣化させる大きな要 因であるMOSFETのチャネル長変調効果の影響を低隇す る手法も併せて提案する。最後に計算機シミュレーション により提案回路の有効性を示す。
2. 従来の第二世代カレントコンベア

第二世代カレントコンベア $(\mathrm{CCII})$ は， $\mathrm{X}, \mathrm{Y}, \mathrm{Z} の 3$ 端 子を有するアナログビルディングブロックであり，そのシ ンボルを図1に示す。それぞれの端子の電圧，電流の関係は

$$
\left[\begin{array}{l}
V_{X} \\
I_{Y} \\
I_{Z}
\end{array}\right]=\left[\begin{array}{rrr}
0 & 1 & 0 \\
0 & 0 & 0 \\
\pm 1 & 0 & 0
\end{array}\right]\left[\begin{array}{l}
I_{X} \\
V_{Y} \\
V_{Z}
\end{array}\right]
$$

という行列で表される。 $\mathrm{Y}$ 端子から $\mathrm{X}$ 端子への電圧伝達と $\mathrm{X}$ 端子から Z 端子への電流伝達を同時に奏現するビルデイ ングブロックである。式 (1)より，Z端子における電流 $I_{Z}$ はX 端子における電流 $I_{\boldsymbol{X}}$ に対し，正あるいは負の極性を 持つ。正の極性を持つものは CCII十，負の極性を持つもの はCCIIーと呼ばれる。

図2に従来のCCII (4)(5)示す。但し, $\mathrm{M}_{\mathrm{p} 1}$ と $\mathrm{M}_{\mathrm{p} 2}, \mathrm{M}_{\mathrm{n} 1}$ と $\mathrm{M}_{\mathrm{n} 2}, \mathrm{M}_{\mathrm{n} 3}$ と $\mathrm{M}_{\mathrm{n} 4}$ のアスペクト比は等しく設計する。 $\mathrm{Y}$ 端子から X 端子への電圧伝達は図 3 に示寸負帰還の原理を 用いている。図3の増幅器の利得を $A$ とすると久出力電死 の関係は

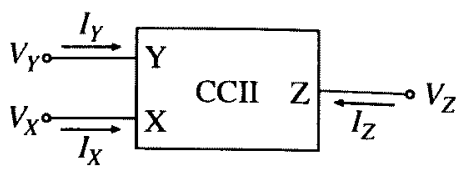

図 1 CCII のシンボル 


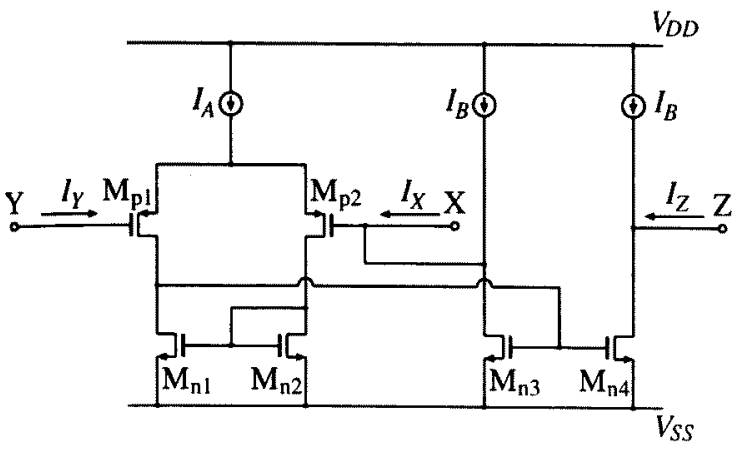

図 2 従来の $\mathrm{CCII}+$

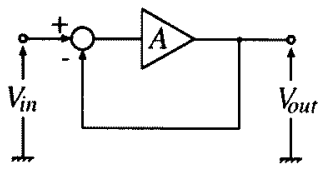

図 3 真帰還回路

$$
V_{\text {out }}=\frac{A}{1+A} V_{\text {in }}
$$

となる。したがって, 増幅器の利得 $A$ が十分大きければ

$$
V_{\text {out }} \simeq V_{\text {in }}
$$

となり，入出力端子の電位が等しくなる。図 2においては 差動增幅回路と $\mathrm{M}_{\mathrm{n} 3}$ のソース接地増幅回路により二段增幅 回路を構成し,これが図 3の増幅器に相当している。この 二段增幅回路の出力端子を反転入力端子に接続することで 負帰還を行っている。また，この归還回路のためにX端子 のインピーダンスを小さくできる(日)。一方，X端子からZ 端子への電流伝達は電流源 $I_{B} と \mathrm{M}_{\mathrm{n} 3}, \mathrm{M}_{\mathrm{n} 4}$ からなるカレ ントミラー回路により

$$
I_{z}=I_{X}
$$

を実現している。したがって，図2に示す回路は CCII+と して動作する。従来回路の問題点として電源間に最大 3 個 のMOSFET が絴積みになっているために低電源電圧下で の動作が困難であることが挙げら机る。さらに電流伝達に おいてX 端子から正電流が入力される場合には，電流源 $I_{B}$ がなくてもカレントミラー回路だけで出力電流 $I_{Z}$ を得る ことができるので， $I_{\boldsymbol{X}}$ が正の場合，無䭾な電力を消費する ことになる。

\section{3. 従来回路の改善}

$\langle 3.1\rangle$ 低電源電生化 図 2 の電流源 $I_{A}$ は差動増幅回 路に流れる電流を入力電圧によらず一定にするという役割 を担っている。飽和領域で動作するMOSFET の伝達コン ダクタンス及びドレイン抵抗は，定電流が流れる限り一定 であるため，㷌還回路部のループ利得 $A$ を一定にできる。

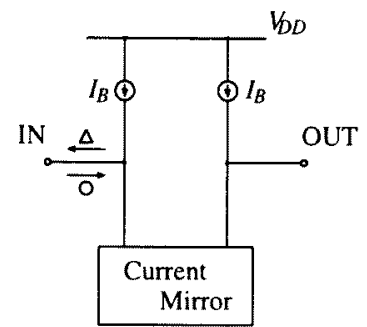

(a) 吸い达み製

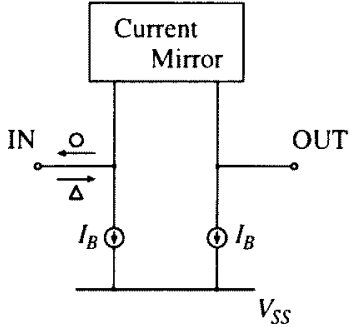

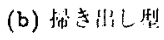

困 4 電流出力段

しかし式 (2)より，ループ利得 $A$ が十分大きけ机ばその值 が変動しても電圧伝達にほとんど影響を与えないことがわ かる。したがって，電流源 $I_{\boldsymbol{A}}$ を削除し， $\mathrm{M}_{\mathrm{p} 1}$ 及び $\mathrm{M}_{\mathrm{p} 2}$ の ソ一ス端子を正電源 $V_{D D}$ に直接接続しても同等の特性を得 ることができる。この構造の問題点として大きな振幅の入 力電圧 $V_{Y}$ が与えられると, 大きなドレイン電流が流れ, 消 費電力の增加につながることが考えられる。しかし、1.5V 程度の電源電圧下では信号振幅は数 $100 \mathrm{mV}$ であり、電流 值はたかだ数倍しか变化しない。また、アプリケーショ ンにもよるが、常に大きな信号が入力されていることは考 えにくい。したがって、電流源 $I_{A}$ の削除は特に問題とは ならない。

〈3・2〉 低消費電力化 図 4(a)に示す吸い込み型カレ ントミラー回路を用いた電流出力段では，正電流 (○力向) が入力される場合はカレントミラー回路が正常に動作でき る範囲で電流を出力することが可能である。しかし負電流 ( $\triangle$ 万向) が入力される場合は入力電流が電流源 $I_{B}$ の值を 越えると，カレントミラー回路を構成する $\mathrm{M}_{\mathrm{n} 3}$ のドレイン 電流が零となり，回路は正常に動作しなくなる。つまり，電 流源 $I_{B} に よ り$ 負の入力電流範囲が制限される。一方, 図 $4(b)$ に示寸掃き出し型カレントミラー回路を用いた電流出 力段では，正電流 ( $\triangle$ 力向) が入力される場合は，電流源 $I_{B}$ により正の入力電流範囲に制限を受けるが，負電流 $(\bigcirc$ 方向)が入力される場合はカレントミラー回路が正常に動 作できる範囲の入力が可能である。したがって，吸い込み 型，掃き出し型のカレントミラー回路を組み合わせること で，電流源 $I_{B}$ が不要の電流出力段を構成できる。

図 5 に提案するCCII+を示す。提案回路は電源間に MOSFETを 2 個だけ縦積みにする構造なので低電源電 圧での動作に向いている。電流伝達に関しては，pチャネ ル MOSFET のしきい電圧の絶対值 $\left|V_{T p}\right|$ と $\mathrm{n}$ チャル MOSFETのしきい電压 $V_{T n}$ の和が電源電压よりも大きい 場合，無信号時には電流出力段に電流が流れず，入力電流 $I_{X}$ の方向により，一方のカレントミラー回路のみが動作す ることで, 従来回路での問題点である無駄な電力の消費を 避けることができる。そのうえ，カレントミラー回路に流 


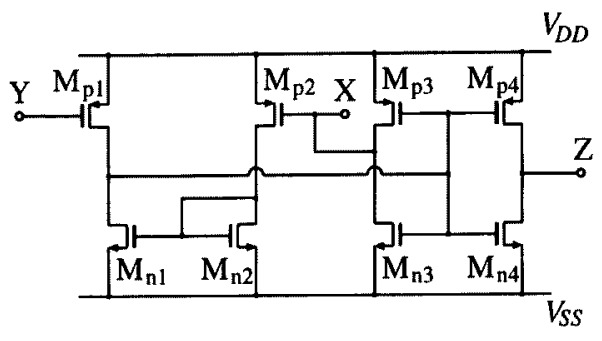

図 $5 \mathrm{CCII}+$ の提案回路

れる電流が $\mathrm{X}$ 端子からの入力電流だけであるので従来回路 よりも大きな入力電流範囲を確保できる。また，電流源を 1 個も用いないので，8個のMOSFETだけで構成でき，チッ プ面積の点でも有利である。さらに，全ての MOSFETに おいてサブストレート端子をソース端子に接続できるので 基板効果の影響を受けないという特徴もある。

次に伝達特性を求める。ここでトランジスタ $\mathbf{M}_{\mathbf{j}}$ の伝達 コンダクタンス及びドレイン抵抗をそれぞれ $g_{m j}$ 及び $\boldsymbol{r}_{d j}$ とする。㷌還路を切断した場合の X 端子から出力へのルー プ利得 $A_{1}$ は

$$
A_{1}=g_{m n 1} g_{m p 2}\left(g_{m p 3}+g_{m n 3}\right) r_{d 1}\left(r_{d 2} / / g_{m n 2}{ }^{-1}\right) r_{d 3}
$$

と表すことができる。但し

$$
r_{d i}=r_{d p i} / / r_{d n i} \quad(i=1,2,3,4)
$$

である。ここでカレントミラー回路及び差動対を成すそれ ぞれの MOSFETの伝達コンダクタンスは等しいとすると， 電圧利得, 電流利得, $\mathrm{X}$ 端子のインピーダンスはそれぞれ

$$
\begin{aligned}
\frac{v_{x}}{v_{y}} & =\frac{1}{g_{m n 1}\left(r_{d 2} / / g_{m n 2}{ }^{-1}\right)} \frac{A_{1}}{1+A_{1}} \\
\frac{i_{z}}{i_{x}} & =\frac{A_{1}}{1+A_{1}} \ldots \ldots \ldots \ldots \ldots \ldots \ldots \ldots \ldots \ldots \ldots \ldots \ldots
\end{aligned}
$$

となる。したがって，增幅器のループ利得 $A_{1}$ が大きい範 囲では電流利得は 1 倍となり，X 端子のインビーダンスの 低減もできる。ドレイン抵抗 $r_{d 2}$ が伝達コンダタタンスの 逆数 $g_{m n 2^{-1}}$ よりも十分大きいとすると電圧利得も 1 倍と なるのでCCII+として動作する。

\section{4. 三段増幅型第二世代カレントコンベア}

$\langle 4 \cdot 1\rangle$ 直流特性の改善 式(2) や式 (8), 式(9) 上り， 增幅器の利得を增加させることが CCII の直流特性の向上 に有効な手法であることがわかる。そこで図 6に増幅回路 の利得を増加させるために三段増幅構成を用いた CCII+を 示す。図6の提案回路は電流源 $I_{p 5}$ 及び $\mathrm{M}_{\mathrm{n} 5}$ からなるソー 不接地堌幅回路が付加された三段増幅回路に負帰還を施し た構造となっている。

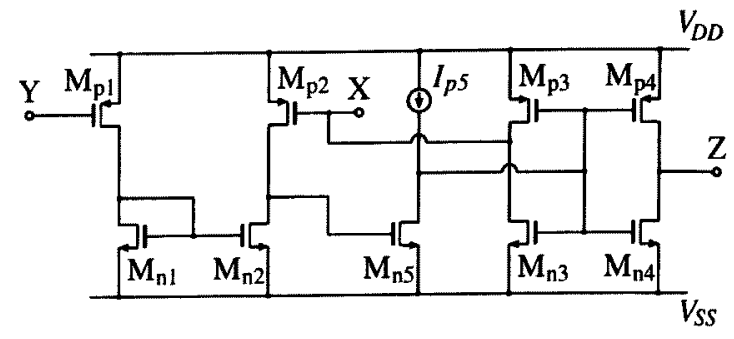

図 6 三段増幅型 CCII+

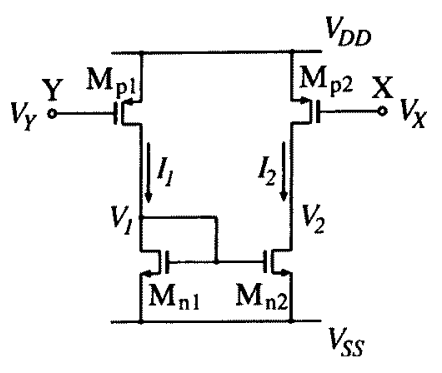

図 7 差動入力段

帰還路を切断した場合の X 端子から出力へのループ利得 $A_{2}$ は

$$
A_{2}=g_{m p 2}\left(g_{m p 3}+g_{m n 3}\right) g_{m n 5} r_{d 2} r_{d 3} r_{d 5}
$$

となる。ここでカレントミラ一回路及び差動対を成すそれ ぞれの MOSFET の伝達コンダクタンスは等しいとすると， $\mathrm{CCII}+$ 電圧利得, 電流利得, $\mathrm{X}$ 端子のインピーダンスは それぞれ

$$
\begin{aligned}
\frac{v_{x}}{v_{y}} & =g_{m n 2}\left(r_{d 1} / / g_{m n 1}{ }^{-1}\right) \frac{A_{2}}{1+A_{2}} \\
\frac{i_{z}}{i_{x}} & =\frac{A_{2}}{1+A_{2}} \cdots \cdots \cdots \cdots \cdots \cdots \cdots \cdots \cdots \cdots \cdots \cdots \cdots \cdots \\
Z_{x} & =\frac{r_{d 3}}{1+A_{2}} \cdots \cdots \cdots \cdots \cdots
\end{aligned}
$$

となる。ここで $g_{m j} r_{d j} \gg 1$ として式 (5) と式 (10)を比較 すると利得 $A_{2}$ は $A_{1}$ と比較して大きいので, 電流利得及 びX 端子のインピーダンスが改善されることがわかる。し かし，式(11)で与之られる電圧利得には式 (7) と同様にド レイン抵抗に関する項があるため利得の増加がさほど特性 の改善につながらない。したがって，電圧特性を改善する ためには增幅回路の利得を増加させるだけでなく、ドレイ ン抵抗を十分大きくすることが必要となる。ドレイン抵抗 を増加させる手法として MOSFETをカスコード接続する ことが知られている。しかし，カスコード接続は電源間に 多くの MOSFET を縦積みにする必要があるので, 低電源 電圧下での動作に不向きである。そこで二段積みで電圧特 性を改善する手法について述べる。

〈4・2〉 チャネル長变調効果の影辢の低減 図 7 CCII の電圧入力段を示す。電圧伝達に誤差を生じる原因は電流 


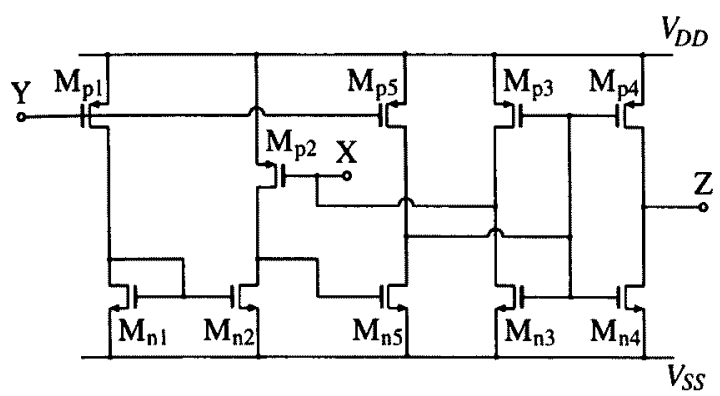

図 8 チャネル長変調効果の影響を低隇した $\mathrm{CCII}+$

$I_{1}$ と $I_{2}$ 並びに電位 $V_{1}$ と $V_{2}$ が異なることである。そこで $I_{1}$ と $I_{2}$ 並びに $V_{1}$ と $V_{2}$ を等しくする手法を述べる。

ドレイン電流は二乗則でほぼ決定されると考えられるが， 実際にはチャネル長変調効果の影響でドレイン・ソース間 電圧 $V_{D S}$ により若干変化する。この影響を考慮した場合， 飽和領域で動作する MOSFET のドレイン電流 $I_{D}$ は

$$
I_{D}=K\left(V_{G S}-V_{T}\right)^{2}\left(1+\lambda V_{D S}\right)
$$

と与えられる。但し，入はチャネル長变調効果係数である。 図 7の $\mathbf{M}_{\mathbf{n} 1}$ と $\mathbf{M}_{\mathbf{n} 2}$ においてゲート・ソース間電圧は等し い。したがって，ドレイン端子の電位を

$$
V_{1}=V_{2}
$$

と等しくすれば， $M_{n 1}$ と $M_{n 2}$ においてチャネル長変調効 果の影響が同等となり

$$
I_{1}=I_{2}
$$

となる。その結果 $\mathrm{M}_{\mathrm{p} 1}, \mathrm{M}_{\mathrm{p} 2}$ においてドレイン電流とドレ イン・ソース間電圧が等しくなるので，式 (14)より

$$
V_{\boldsymbol{X}}=V_{\boldsymbol{Y}}
$$

となる。そこでドレイン電位 $V_{1} と V_{2}$ を等しくできる三段 増幅型 CCII を図 8に示す。MOSFETのアスペクト比を $\mathrm{M}_{\mathrm{p} 1}, \mathrm{M}_{\mathrm{p} 2}, \mathrm{M}_{\mathrm{p} 5}$ で等しく, $\mathrm{M}_{\mathrm{n} 1}, \mathrm{M}_{\mathrm{n} 2}, \mathrm{M}_{\mathrm{n} 5}$ で等しくす る。 $M_{\mathrm{p} 1}$ と $\mathrm{M}_{\mathrm{p} 5}$ のゲート・ソース間電压は等しいので, 二 乗則を仮定すると等しいドレイン電流が流れ， $\mathrm{M}_{\mathbf{n} 1}$ と $\mathrm{M}_{\mathbf{n} 5}$ のドレイン電流も等しくなる。たとえ式 (14)を仮定したと しても $\mathrm{M}_{\mathrm{n} 1}$ と $\mathrm{M}_{\mathrm{n} 5}$ ，それぞれのゲート・ソース間電圧はほ ほ等しくなり， $\mathrm{M}_{\mathrm{n} 1}$ と $\mathrm{M}_{\mathrm{n} 2}$ のドレイン・ソース間電圧がほ は等しく保たれる。したがって， $\mathrm{M}_{\mathrm{p} 1}$ と $\mathrm{M}_{\mathrm{p} 2}$ のドレイン 電流もほほ等しくなるので，Y 端子から X 端子への電圧伝 達が改善される。

図 8に示す CCII+の電流利得, $\mathrm{X}$ 端子のインピーダンス はそれぞれ式 (12)，式 (13) と同じであるが，電圧利得は

$$
\begin{aligned}
\frac{v_{x}}{v_{y}} & =\left\{g_{m n 2}\left(r_{d 1} / / g_{m n 1}{ }^{-1}\right)+\frac{1}{g_{m n 5} r_{d 2}}\right\} \frac{A_{2}}{1+A_{2}} \\
& =\frac{1+g_{m n 1} r_{d 1}\left(1+g_{m n 1} r_{d 1}\right)}{g_{m n 1} r_{d 1}\left(1+g_{m n 1} r_{d 1}\right)} \frac{A_{2}}{1+A_{2}} \cdots(18
\end{aligned}
$$

となる。但し

$$
\begin{aligned}
g_{m n 1} & =g_{m n 2}=g_{m n 5} \\
r_{d 1} & =r_{d 2} \ldots \ldots
\end{aligned}
$$

と仮定している。式 (18) ではドレイン抵抗 $r_{d 1}$ が $\left(1+g_{m n 1} r_{d 1}\right)$ 倍されたのと等価であり，式 (11) と比較し て電圧伝達特性が改善されていることがかかる。

図6及び図8に示すCCII+は三段增幅回路に負帰還を施 した構造になっているので位相補償をする必要がある。そ こで, $\mathbf{M}_{\mathbf{n} 3}$ のゲート・ドレイン間に容量と抵抗を直列接続 した回路を付加することで位相補償を行っている。

\section{5. シミュレーション}

電源電圧を $1.5 \mathrm{~V}$ ，入力電流範囲を $\pm 100 \mu \mathrm{A}$ として $\mathrm{CCII}+$ のシミュレーションを行う。電流源は $I_{A}$ を $4 \mu \mathrm{A}$ ， $I_{B}$ を $100 \mu \mathrm{A}, I_{p 5}$ を $2 \mu \mathrm{A}$ とする。また，各 MOSFETの チャネル幅 $W$ ，チャネル長 $L$ を表 1 に示す。ここで，従来 回路の $\mathrm{M}_{\mathrm{n} 3}, \mathrm{M}_{\mathrm{n} 4}$ のチャネル幅は提案回路と比較して大き く設計している。この理由は, 従来回路では電流出力段の バイアス電流が大きいために $\mathrm{M}_{\mathrm{n} 3}, \mathrm{M}_{\mathrm{n} 4}$ のゲート電位が高 くなり， $\mathrm{M}_{\mathrm{p} 1}$ が飽和領域からはずれて回路が正常に動作し なくなるのを防ぐためである。また，位相補償用回路とし て図 6及び図 8 では容量 $1 \mathrm{pF}$ と抵抗 $64 \mathrm{k} \Omega$ を用いている。 但し，抵抗は非飽和領域で動作するMOSFETで代用して

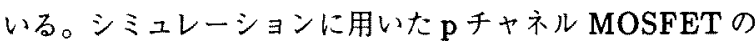
しきい電圧 $V_{T p}$ 、n チャネル MOSFET のしきい電压 $V_{T n}$ はそれぞれ $-0.78 \mathrm{~V} 、 0.75 \mathrm{~V}$ である。

入力電压 $V_{Y}$ を $0.4 \mathrm{~V}$ ，入力電流 $I_{X}$ を $0 \mathrm{~A}$ とすると式 $(1)$ に対応する以下の伝達行列が得られる。

従来回路 (図 2)

$$
\left[\begin{array}{l}
v_{x} \\
i_{y} \\
i_{z}
\end{array}\right]=\left[\begin{array}{ccc}
118 & 1.02 & 0 \\
0 & 0 & 0 \\
0.998 & -21.2 \mu & 20.8 \mu
\end{array}\right]\left[\begin{array}{l}
i_{x} \\
v_{y} \\
v_{z}
\end{array}\right]
$$

\begin{tabular}{|c|c|c|}
\hline & \multicolumn{2}{|c|}{$W / L$} \\
\hline & 往来[i门]路 & 提案问斎 \\
\hline $\mathbf{M}_{\mathrm{p} 1}, \mathbf{M}_{\mathrm{p} 2}, \mathbf{M}_{\mathrm{p} 5}$ & $2 \mu \mathrm{m} / 2 \mu \mathrm{m}$ & $2 \mu \mathrm{m} / 2 \mu \mathrm{m}$ \\
\hline $\mathbf{M}_{\mathrm{n} 1}, \mathbf{M}_{\mathrm{n} 2}, \mathbf{M}_{\mathrm{n} 5}$ & $8 \mu \mathrm{m} / 2 \mu \mathrm{m}$ & $8 \mu \mathrm{m} / 2 \mu \mathrm{m}$ \\
\hline$M_{p_{3}, M_{p^{4}}}$ & - & $28 \mu \mathrm{m} / 2 \mu \mathrm{m}$ \\
\hline$M_{n 3}, M_{n 4}$ & $80 \mu \mathrm{m} / 2 \mu \mathrm{m}$ & $12 \mu \mathrm{m} / 2 \mu \mathrm{m}$ \\
\hline
\end{tabular}

提案回路 1 (図 5 )

$$
\left[\begin{array}{l}
v_{x} \\
i_{y} \\
i_{z}
\end{array}\right]=\left[\begin{array}{ccc}
1.66 \mathrm{k} & 1.06 & 0 \\
0 & 0 & 0 \\
0.998 & -1.36 \mu & 1.27 \mu
\end{array}\right]\left[\begin{array}{l}
i_{x} \\
v_{y} \\
v_{z}
\end{array}\right]
$$

提案回路 2 (図 6 )

$$
\left[\begin{array}{c}
v_{x} \\
i_{y} \\
i_{z}
\end{array}\right]=\left[\begin{array}{ccc}
98.5 & 0.941 & 0 \\
0 & 0 & 0 \\
1.00 & -1.20 \mu & 1.27 \mu
\end{array}\right]\left[\begin{array}{l}
i_{x} \\
v_{y} \\
v_{z}
\end{array}\right]
$$

表 1 MOSFET 


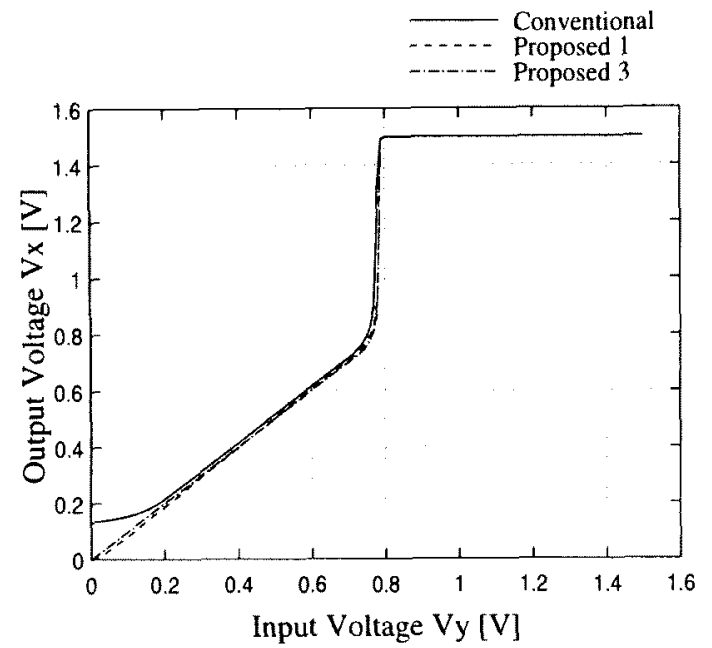

図 9 電圧伝達特性

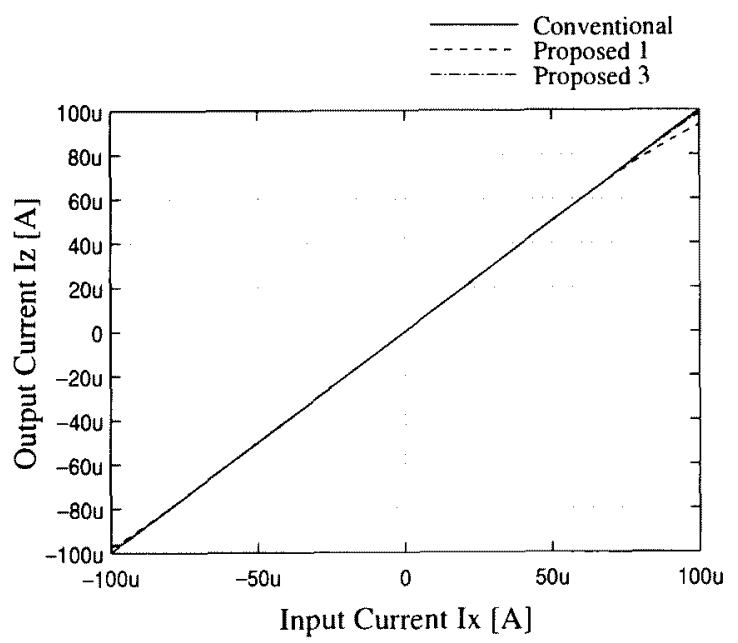

図 10 電流伝達特性

提案回路 3 (図 8)

$$
\left[\begin{array}{c}
v_{x} \\
i_{y} \\
i_{z}
\end{array}\right]=\left[\begin{array}{ccc}
98.9 & 1.004 & 0 \\
0 & 0 & 0 \\
1.00 & -1.28 \mu & 1.27 \mu
\end{array}\right]\left[\begin{array}{l}
i_{x} \\
v_{y} \\
v_{z}
\end{array}\right]
$$

式 $(24)$ と式 $(21) \sim(23)$ とを比較すると, 提案回路 3 で は良好な電压利得が得られている。これよりチャネル長変 調効果の影響の低減が電压利得の改善に有効であることが 確認できる。電流利得とX 端子のインピーダンスに関して は，ループ利得が高い方が良好な結果となることが確認で きる。また，従来回路のインピーダンスが低くなっている のは，電流出力段のバイアス電流が大きいためである。

$\mathrm{Y}$ 端子に入力電圧 $V_{Y}$ を加えた場合の直流電圧特性を図 9 に示す。従来回路よりも提案回路は広い入力電圧範囲を実 現している。これは、提案回路では電流出力段を流れるバ

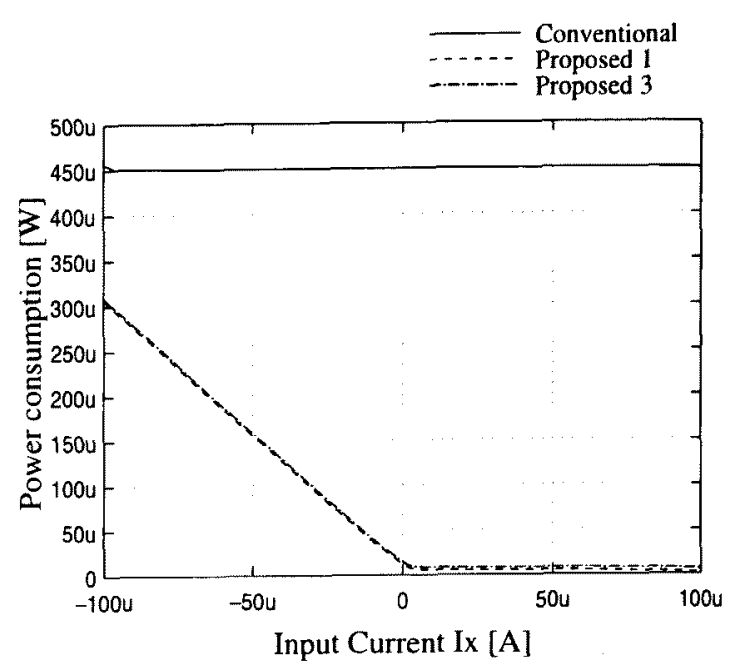

図 11 消費電力特性

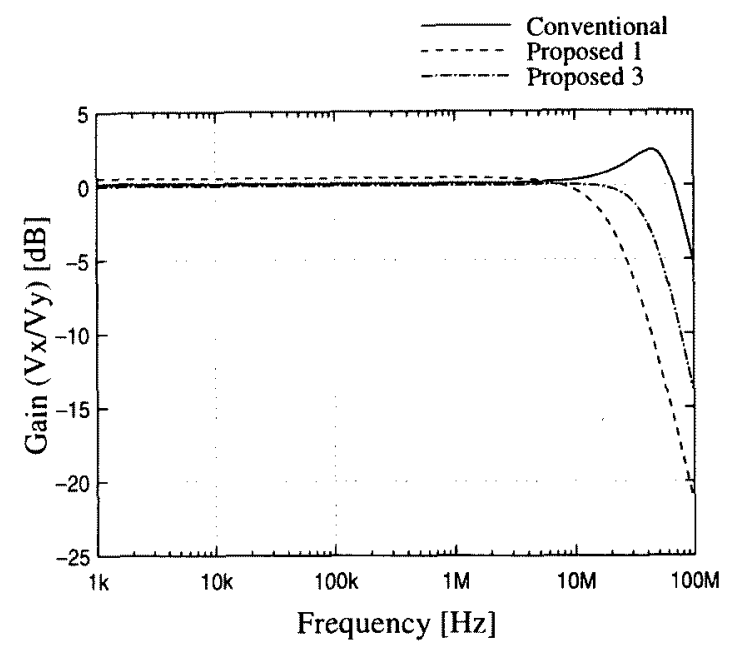

図 12 電圧利得の周波数特性

イアス電流が小さいので $\mathrm{M}_{\mathrm{n} 3}$ 及び $\mathrm{M}_{\mathrm{n} 4}$ のゲート電位、つ まり $\mathrm{M}_{\mathrm{p} 1}$ または $\mathrm{M}_{\mathrm{p} 2}$ のドレイン電位が小さくなり、入力電

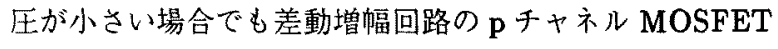
が飽和領域で動作できるためである。また，入力電圧が約 $0.8 \mathrm{~V}$ 越えたところから動作しない理由は，差動入力段の p チャネル MOSFETのゲート・ソース間電圧がしきい電 压を下回り，ドレイン電流が減少して $\mathrm{M}_{\mathbf{n} 1}, \mathrm{M}_{\mathbf{n} 2}$ からなる カレントミラー回路が正常に動作しなくなるためである。

$\mathrm{X}$ 端子に入力電流 $I_{X}$ を加えた場合の直流電流特性を図 10 に示す。提案回路 1 では大きな正電流が入力されると $\mathrm{M}_{\mathrm{n} 3}$ と $\mathrm{M}_{\mathrm{n} 4}$ が非飽和領域に入り，カレントミラー回路として正 常に動作しなくなるために，出力電流が小さくなっている。 これはMOSFETのアスペクト比を大きくすることで解決 できる。また，提案回路 3 では提案回路 1 と同じアスペク 卜比の MOSFET 用いているが, 出力電流の減少が低滅 


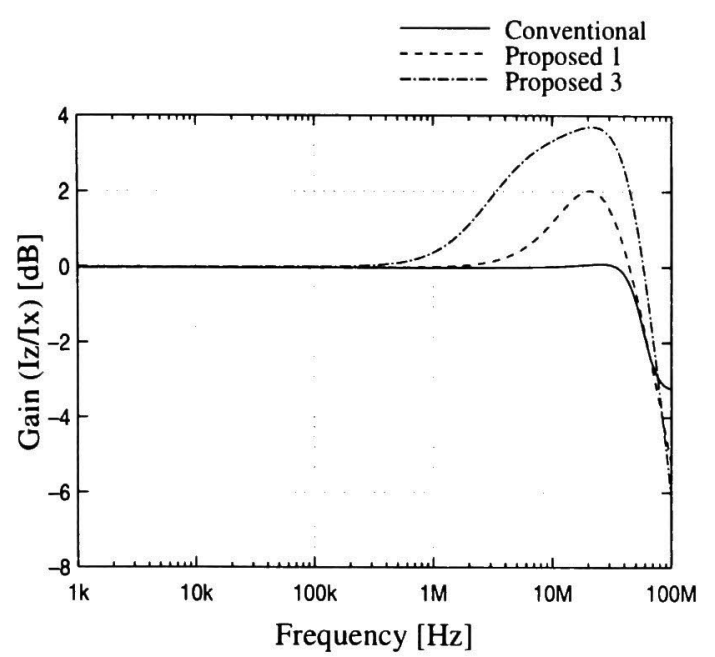

図 13 電流利得の周波数特性

されている。この理由は, 式(22), 式(24)に示されるよう に提案回路 3 では X 端子のインピーダンスの低減が赛現さ れ, 入力電流が大きい場合においても $\mathrm{M}_{\mathrm{n} 3}$ と $\mathrm{M}_{\mathrm{n} 4}$ のドレ イン・ソース間電圧はほぼ等しく保たれるためである。

図 11 に入力電流 $I_{X}$ に対する消費電力を示す。提案回路 では入力電流が負の場合に電源 $V_{D D}$ から入力電流值に応じ た電流が供給され，正の場合は供給が不要となるため, 消 費電力の低減が実現されている。

図 12 に示す電圧利得の周波数特性においては, 提案回 路では位相補償を行っているため, 従来回路にはやや劣る が良好な結果となっている。また, 図 13 に示す電流利得の 周波数特性においては, 従来回路では $38 \mathrm{MHz}$ 付近までほ ほ理想通りに動作するのにもかかわらず、提案回路 1 では $2.6 \mathrm{MHz}$ 、提案回路 3 では $500 \mathrm{kHz}$ 付近から利得が増加し 始めるため動作範囲が $1 / 10$ 以下となっている。この原因 は提案回路では位相補償容量により, 提案回路 1 では主と なる極 $\left|p_{1}\right|$ 及び零点 $\left|z_{1}\right|$ はそれぞれ $26 \mathrm{MHz}$ 及び $13 \mathrm{MHz}$ 、 提案回路 3 では主となる極及び零点はそれぞれ $3.5 \mathrm{MHz}$ 及 び $2.4 \mathrm{MHz}$ となり、極よりも小さい周波数の零点ができ, その零点の影響を受けるためである。

\section{6. 結 論}

本論文では，電源間にMOSFETを 2 個だけ縦積みとす ることで，低電源電圧下での動作を可能とした CCII+を 提案した。入力電流の方向に応じて一部の回路だけが動作 する電流出力段を用いることで, 無信号時のバイアス電流 を零に近づけ，大幅な消費電力の低減を実現した。また， MOSFET のチャネル長変調効果の影響を低減することで 電圧伝達の改善を実現した。提案回路の計算機シミュレー ションにおいて良好な結果を得た。

今後の課題としては, 周波数特性の改善や CCII の特徵 を生かした応用、フィルタの設計などが挙げられる。

電学論C, 120 巻 10 号, 平成 12 年

\section{謝 辞}

本研究の一部は文部省科学研究費補助金 (基盤研究 (B)(2)) 研究課題番号 11450145 の援助のもとで行われた ものである。

(平成 12 年 3 月 7 日受付, 同 12 年 7 月 4 日再受付)

\section{文献}

(1) A. Sedra and K. C. Smith: "A Second-Generation Current Conveyor and its Applications," IEEE Trans. Circuit Theory, vol. CT-17, pp.132-134, Feb. 1970.

(2) B. Wilson: "Floating FDNR employing a new CCII- conveyor implementation," Electron. Lett., vol.21, no.21, pp.996-997, Aug. 1985.

(3) S.-I. Liu, H.-W. Tsao, J. Wu and T.-K. Lin: "MOSFET capacitor filters using unity gain CMOS current conveyors," Electron. Lett., vol.26, no.18, pp.1430-1431, Aug. 1990.

(4) E. Ibaragi, A. Hyogo and K. Sekine: "A Novel CMOS OTA free from Mobility Reduction," Proc.APCCAS'98, pp.241244, Nov. 1998.

(5) R.-M. Weng, C.-L. lin and M.-H. Lee: "A Class of TwoCurrent-Conveyor-Based Oscillators Employing Minimum Grounded Passive Elements," Proc.APCCAS'98, pp. 267-269, Nov. 1998.

(6) O. Oliaei and J. Porte: "Compound current conveyor (CCII+ and CCII-)," Electron. Lett., vol.33, no.4, pp.253-254, Feb. 1997.

今 関

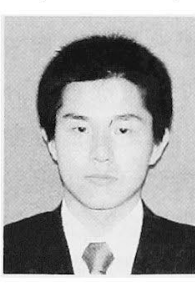

高 木茂 孝 (正員) 昭 56 東工大·電気電子卒。昭 61 同大大

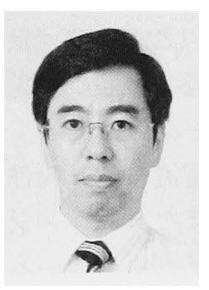

藤 井 信生 (正員) 昭 41 慶大·工・電気卒. 昭 43 東工大·

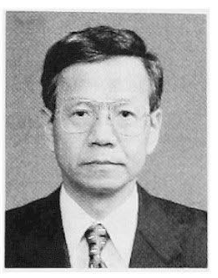
大学院修士, 昭 46 同博士課程了. 工博. 同年東 工大. 工. 助手. 昭 50 同助教授, 昭和 63 同教授. 昭 54-55カリフォルニア大学サンタバーバラ校客 員研究員. 電子情報通信学会米澤記念学術奨励賞, 論文賞受賞. 電子回路, 回路網理論, 能動フィル 夕などの研究に従事. 著書「アナログ電子回路」 (昭晃堂),「なっとくする電子回路」(講談社)など. 電子情報通信学会, IEEE 各会員， 工大·集積システム専攻・助教授。平 10 年度大阪 大客員助教授。電子情報通信学会昭 63 年度篠原 記念学術奖励賞, 平 7 年度論文賞受賞。アナログ 集皘回路の研究に従事。著書「MOSアナログ電 子回路」(昭晃堂),「ディジタル集積回路入門」(共 著, 昭晃堂)。電子情報通信学会, IEEE 各会員。 